\title{
Musisi Muda, Institusi Pendidikan dan Komunitas Musik ${ }^{1}$
}

\section{INTRO}

Dalam kajian kepemudaan, pembahasan mengenai musisi muda seringkali hanya dibingkai dengan perspektif budaya kaum muda (youth culture). Perdebatan yang muncul dalam beberapa studi-studi terdahulu misalnya bergulat pada isu mengenai apakah musisi muda dan musik merupakan manifestasi dari subculture (Blackman 2005) ataukah post-subculture (Bennett 1999). Secara sederhana, aktivitas kaum muda dengan medium musik oleh para teoritikus kajian kepemudaan dipertentangkan apakah merupakan refleksi dari background kelas sosial mereka ataukah manifestasi dari inisiatif individual dalam kerangka neotribe yang justru berkarakter cair, fleksibel dan terfragmentasi. Keduanya sangat kental dengan pendekatan cultural studies sebagaimana dimunculkan oleh mahzab Birmingham dan tentu saja produksi pengetahuan ini tidak terlepas dari konteks sosial budaya di Inggris pada waktu itu. Dalam kenyataan empiris, kedua perspektif tersebut dapat ditemukan dalam berbagai kasus musisi muda dan komunitas musik serta sangat mungkin beririsan satu sama lain antara bentuk subculture dengan postsubculture. Keterbukaan pola pikir dan sensitivitas dalam proses penelitian maupun penulisan merupakan hal penting supaya terhindar dari dikotomi pengetahuan yang cenderung mengkotakkotakkan, berujung hegemoni dan berakibat pada tidak dimunculkannya 'suara' subjektif dari musisi yang diteliti.

Berdasarkan hasil refleksi saya sebagai musisi sekaligus peneliti, perspektif budaya kaum muda cenderung mereduksi berbagai aktivitas musisi muda hanya sebatas persoalan identitas, gaya hidup, politik representasi ataupun bentuk resistensi terhadap budaya mainstream. Selain itu seringkali perspektif budaya kaum muda terlalu terfokus pada sisi permukaan dan kedangkalan dari aktivitas musisi muda tersebut. Kecenderungan ini menurut saya menafikkan beberapa aspek penting yang ditawarkan oleh perspektif transisi pemuda mengenai pentingnya peran institusi sosial misalnya lembaga pendidikan dan komunitas dalam proses transisi antar domain serta sebagai ruang untuk berproses menjadi dewasa sekaligus pematangan skill-skill musikal dan nonmusikal untuk melanjutkan ke jenjang professional. Dalam memahami kompleksitas kehidupan musisi muda, kedua perspektif tersebut sebenarnya dapat digunakan sebagai tool of analysis yang berguna dan saling melengkapi satu sama lain. Dengan kata lain, dalam memahami musisi muda dibutuhkan pendekatan yang

\footnotetext{
${ }^{1}$ Beberapa bagian dari esai ini diterjemahkan dan direvisi seperlunya dari salah satu sub-bab disertasi penulis berjudul "Young Indonesian Musicians: Making Transition to Adulthood through Entrepreneurial Activities and Mobility" (2016).
} 
dapat menjembatani antara perspektif budaya dengan perspektif transisi.

Dalam esai ini, saya akan mencoba asi kontribusi dari institusi pendidikan dan komunitas musik bagi musisi muda pada masa transisi menuju jenjang profesional. Pendekatan yang digunakan menjembatani antara perspektif budaya dengan perspektif transisi terutama melalui theory of practice dari Pierre Bourdieu (Bourdieu \& Wacquant, 1992). Perangkat analisis dari Bourdieu seperti ranah, kapital, habitus, doxa relevan dan applicable dalam menjembatani kedua perspektif tersebut. Argumen dalam esai ini didasarkan pada refleksi kritis terhadap hasil penelitian saya mengenai musisi muda di Yogyakarta, Jakarta dan Bali.

\section{PENDIDIKAN SEBAGAI JALAN PEMBUKA}

Pendidikan merupakan faktor yang penting dalam proses transisi musisi muda namun bukan menjadi jaminan utama bagi kesuksesan karir maupun menuju kedewasaan di masa depan. Pendidikan hanya menjadi alat, manifestasi kapital budaya (Bourdieu, 1986) dan sebagai ruang untuk menginternalisasi habitus sekunder/ secondary habitus (Wacquant, 2014). Dalam mewujudkan keberlanjutan perjuangan dalam masa transisi, diperlukan ketersediaan bentuk-bentuk kapital yang beragam dan fleksibilitas dalam merekonstruksi kapital di berbagai ranah perjuangan yang berbeda-beda. Dengan kata lain, hal tersebut bergantung pada kemampuan reflektif musisi muda untuk mengaktifkan disposisi yang beragam/multiple dispositions (Lahire, 2003) dalam menghadapi ketidakpastian masa depan sebagai musisi professional. Pendidikan menjadi kapital dasar yang penting dalam mengantisipasi resiko ketidakpastian di masa depan.

Dalam kasus musisi muda, institusi pendidikan formal berperan sebagai ranah di mana musisi berjuang mengakumulasi kapital-kapital yang berharga sebagaimana direproduksi melalui doxa yang didukung oleh para agen-agen yang dominan (Bourdieu \& Wacquant, 1992). Institusi pendidikan formal menjadi representasi dari reproduksi mode pengajaran musik yang ketat, kaku dan terstruktur. Mode produksi pengetahuan ini bertujuan untuk menciptakan pembedaan/distinction (Bourdieu, 1984) bagi institusi pendidikan itu sendiri dan juga bagi mereka yang terlibat dan memperoleh legitimasi simbolik dari institusi tersebut termasuk para musisi muda. Legitimasi simbolik dan privilege dari institusi pendidikan ini dalam prosesnya secara tidak langsung juga dilegitimasi oleh negara dan industri musik. Kenyataan objektif ini menguntungkan musisi muda yang mencoba mengembangkan karir bermusiknya. Simbiosis mutualisme antara negara, industri dan musisi muda ini termanifestasi melalui konversi kapital dimana secara implisit mereka saling menguatkan posisi satu sama lain dalam ranah yang lebih luas.

Meskipun legitimasi simbolik dan rekognisi dari institusi pendidikan formal merupakan wujud kapital budaya yang penting namun harus diingat bahwa musisi muda sekarang ini tumbuh dan mengembangkan karir bermusik mereka dalam konteks perubahan sosial yang terjadi secara masif (Wyn \& Woodman, 2007) dan dalam cengkeraman neoliberal governmentality (Kelly, 2006). Sebagai dampak dari berbagai faktor luar tersebut serta mekanisme internal dalam ranah perjuangan itu sendiri, sangat besar kemungkinannya bagi kapital budaya yang 
didapatkan oleh musisi muda untuk kehilangan nilai keberhargaannya saat ditukarkan dengan kapital yang lain. Hal ini sangat mungkin terjadi jika musisi muda tersebut tidak mampu mengkombinasikannya dengan kapitalkapital yang lain terutama embodied cultural capital (Bourdieu, 1986) dan kapital sosial strategis dan berkelanjutan (durable and strategic social capital). Di sini relevansi sub-judul di atas dimana dalam era sekarang, pendidikan hanya sebagai jalan pembuka bukan menjadi jaminan utama bagi musisi muda. Para musisi muda harus lebih kreatif mengakumulasi kapital-kapital yang lain dari ranah perjuangan yang berbeda salah satunya melalui berbagai macam komunitas musik yang ada di kota-kota mereka.

\section{KOMUNITAS MUSIK SEBAGAI SUMBER BERBAGI KAPITAL NON- FORMAL}

Bagi musisi muda, sumber-sumber kapital tidak hanya berasal dari institusi pendidikan formal. Secara refleksif, musisi muda sadar mengenai pentingnya komunitas musik. Dengan bergabung pada komunitas musik, menjadi fleksibel dan secara aktif menerapkan mode reflexive habitus (Sweetman, 2003), para musisi muda mendapatkan peluang lebih untuk mengakumulasi berbagai macam kapital berharga yang relevan untuk berjuang dalam ranah musik yang beragam dan bertingkat. Bentuk ideal dari akumulasi kapital ini adalah perpaduan antara keduanya. Selain itu, musisi muda juga perlu berkomitmen dan menginvestasikan waktunya untuk menyerap proses penubuhan (embodiment) dari kapital budaya tidak hanya melalui tubuh namun juga secara mental dan emosional (Wacquant, 2014). Dikarenakan para musisi muda ini telah berkomitmen dan berpartisipasi secara penuh dalam karir yang secara ontologis tidak pasti, mempunyai kemampuan untuk memadukan dan menerjemahkan ulang berbagai macam kapital berharga yang didapat dari institusi pendidikan dan komunitas musik menjadi strategi yang paling realistis dan cerdik supaya terhindar dari resiko ketidakpastian di masa depan. Dalam kasus musisi muda, bentuk refleksivitas khusus ini telah secara mendalam terindividualisasi dan diaktifkan secara kreatif dalam komunitas musik yang mencerminkan perpaduan antara karakter subculture dan post-subculture (Bennett, 1999; Blackman, 2005).

Berkebalikan dengan institusi pendidikan formal yang secara berkelanjutan mereproduksi moda produksi pengetahuan yang ketat dan terstruktur, dalam komunitas musik, musisi muda secara tidak sadar dilatih baik secara individual maupun kolektif tentang bagaimana mengaktifkan dan merekonstruksi kapital budaya secara fleksibel pada kondisi 'real' dalam ranah musik. Melalui mekanisme magang yang termanifestasikan melalui jam sessions, bermain musik di panggung termasuk mekanisme informal 'belakang panggung', para musisi muda belajar mengenai bagaimana menyesuaikan dan beradaptasi dengan tekanan yang beragam dan daya tarik (gravity) dari ranah perjuangan. Para musisi muda juga belajar bagaimana satu langkah lebih maju untuk keluar dari zona nyaman mereka baik secara mental, tubuh dan emosional. Selain itu, doxa yang direproduksi secara berkelanjutan dalam komunitas musik tidak hanya memfasilitasi musisi muda untuk berkembang secara individual namun juga menyediakan ruang belajar untuk berjuang bersama dan untuk 
berbagi berbagai macam kapital yang berharga dengan musisi muda yang lain. Dengan kata lain, secara objektif, komunitas musik dalam scope ranah perjuangan yang lebih luas memposisikan dirinya sebagai ruang produksi bagi profesi yang bersifat spesifik, dalam kasus ini profesi sebagai musisi. Jauh dari kesan ekslusif, komunitas musik memposisikan dirinya sebagai batu pijakan dan jembatan strategis bagi musisi muda supaya ke depan bisa berjuang dengan sukses dalam ranah musik yang lebih tinggi.

Peran penting komunitas musik bagi musisi muda adalah sebagai pendorong budaya inklusif dan fleksibilitas dalam mengumpulkan serta memadukan beragam titik kapital sosial. Peran ini memfasilitasi musisi muda untuk berbagi kapital budaya dengan sesama musisi yang lain. Karakter inklusif ini mempunyai dua dampak utama: Pertama, mengoptimalkan musisi muda untuk mengakumulasi kapital sosial dalam jumlah lebih sekaligus terkait dengan elemen strategis dari kapital tersebut. Kedua, menjaga ketersediaan kapital budaya yang ter-update berdasarkan perubahan secara konstan dan masif dari rule of the game dalam komunitas musik yang beragam dan bertingkat. Komunitas musik tidak hanya menunjukkan karakter inklusif dengan sesama ranah budaya yang lain namun secara internal, komunitas musik melalui doxa (Bourdieu \& Wacquant, 1992) yang terus direproduksi sendiri mampu memfasilitasi peningkatan dan keberlanjutan solidaritas antara musisi muda tersebut. Dengan kata lain, komunitas musik menjadi ruang produksi dan ruang berbagi emosi antar musisi muda. Hal ini tidak berlangsung secara sempit berdasarkan logika pertukaran rasional ataupun berdasarkan logika homo economicus, yang terjadi justru lebih dalam dari itu. Kapital sosial strategis (strategic social capital) sebagai bentuk solidaritas dan berbagi emosi antar musisi muda termanifestasi dalam kesetiaan dan keberlanjutan hubungan sosial baik saat mereka mengalami masa susah maupun senang tidak hanya di masa lalu namun juga berbagi komitmen bersama di masa sekarang dan masa depan. Bentuk kapital sosial strategis dan berkelanjutan ini memainkan peran penting ketika para musisi muda memutuskan untuk pindah baik secara temporer maupun permanen ke kota lain untuk mengejar karir musik yang lebih tinggi di masa depan.

\section{OUTRO}

Penjelasan tersebut menunjukkan pentingnya peran institusi pendidikan formal dan komunitas musik dalam proses transisi musisi muda menuju jenjang karir yang lebih tinggi. Selain itu, juga telah ditunjukkan mengenai kompatibilitas theory of practice dari Bourdieu dalam menjembatani perspektif budaya dan perspektif transisi. Bagi musisi muda, ranah budaya dan transisi saling berkaitan dan bersimpangan satu sama lain dalam realitas kehidupan sehari-hari. Secara ideal, untuk mencapai kesuksesan dalam bermusik dan menghindari resiko ketidakpastian di masa depan, musisi muda harus mengkombinasikan berbagai macam kapital yang disediakan baik oleh institusi pendidikan formal maupun komunitas musik dan secara refleksif mengadaptasikan berbagai macam kapital tersebut saat menghadapi ranah perjuangan yang berbeda.

\section{DAFTAR PUSTAKA}

Bennett, Andy 1999,'Subcultures or Neotribes? rethinking the relationship between youth, style and musical 
taste', Sociology, Vol. 33, No. 3, pp. 599-617.

Blackman, Shane 2005, 'Youth subcultural theory: a critical engagement with the concept, its origins and politics, from the Chicago school to postmodernism', Journal of youth studies, Vol. 8, No. 1, pp. 1-20.

Bourdieu, Pierre 1984, Distinction: A Social Critique of the Judgement of Taste, Translated by Richard Nice, Harvard University Press, Cambridge

Bourdieu, Pierre 1986, 'The forms of capital', in J. Richardson (ed.) Handbook of Theory and Research for the Sociology of Education, Greenwood, New York.

Bourdieu, Pierre \& Wacquant L 1992, an Invitation to Reflexive Sociology, Polity Press, Cambridge.

Kelly, Peter 2006, 'The entrepreneurial self and youth at risk', Journal of Youth Studies, Vol. 9 No1, pp. 17-32.

Lahire, Bernard 2003, 'From the habitus to an Individual heritage of Dispositions: Towards a sociology at the level of Individual', Poetics Vol. 31 No. 5-6, pp. 329-355.

Sweetman, Paul 2003, 'Twenty first century dis-ease? Habitual reflexivity of reflexive habitus', The Sociological Review Vol. 51 No. 4, pp. 528-549.

Wacquant, Loic 2014, 'Homines in Extremis: What Fighting Scholars Teach Us about Habitus', Body \& Society, Vol. 20 No. 2, pp. 3-17.

Wyn, Johanna \& Woodman, Dan 2007, 'Researching Youth in the Context of Social Change: A Reply to Roberts', Journal of Youth Studies, Vol. 10 No. 3, pp. 373-381. 